кандидат педагогічних наук, старший науковий співробітник (Інститут проблем виховання НАПНУ, м. Київ) necherda@gmail.com ORCID: 0000-0003-2571-5785

\title{
ФОРУМ-ТЕАТР ЯК ФОРМА РЕАЛІЗАЦІЇ "ФІЛОСОФІЇ ДЛЯ ДІТЕЙ": ДО ПИТАННЯ ВИХОВАННЯ ПІДЛІТКІВ УРАЗЛИВИХ КАТЕГОРІЙ
}

Стаття присвячена деяким питанням виховання підлітків уразливих категорій у загальноосвітньому навчальному закладі. Автор розкриває переваги методики "Філософія для дітей", зокрема, такої форми ї̈ реалізації як шкільний театр. В иентрі уваги дослідника особливості форум-театру як інтерактивної форми навчання й виховання учнів та його ефективність в роботі з підлітками уразливих категорій.

Ключові слова: уразливість, шкільний театр, креативне мислення, критичне мислення, піклувальне мислення.

Постановка проблеми. На сьогодні в Україні одна з найгостріших проблем - уразливість сучасної дитини, підлітка зокрема. Все більше осіб у віці 11-15 років починають практикувати ризиковану поведінку, зростає кількість правопорушень неповнолітніх, а також проявів агресії і насильства у навчально-виховному середовищі. Переважна більшість сучасних підлітків уразливих категорій, що схильні до ризикованих способів міжособистісних та групових взаємодій, беруть на себе роль пасивного слухача, а не активного партнера по спілкуванню, відрізняються нетерпимістю, упередженістю, байдужою громадською позицією, проявами асоціальної поведінки та формальним мисленням. Однак ще видатний педагог В. Сухомлинський наголошував, що "за своєю природою діти не можуть бути "важкими", "поганими", а стають такими лише через помилки у вихованні та умови, в яких вони перебувають" [1: 149]. Саме тому в роботі із зазначеними категоріями підлітків перевага має надаватися таким виховним заходам, які спрямовані на розвиток креативності, відповідальності, альтруїстичності, культури мовлення і комунікаційних навичок, а також на активне свідоме самовиховання учнів, залучення ними сили волі для подолання властивих цьому віку проблем особистісного й міжособистісного характеру (не сформованість внутрішньої позиції, відсутність комунікативної компетентності, комплекс неповноцінності й ін.) та формування імунітету до шкідливих впливів соціального оточення.

Відтак необхідним є створення позитивного емоційного клімату школи, активізація творчого потенціалу учнів, розвиток їх загальної культури та особистості в цілому. Досягненню цих завдань найбільше сприяє залучення вихованців до творчої, зокрема, театральної діяльності у навчально-виховному закладі. Вона зумовлює особливий вид взаємодії педагогів і учнів, основу якого складає атмосфера свободи самовираження, заохочення оригінальності й ініціативи кожного, відсутність певного зразка для наслідування, наявність власної точки зору всіх учасників. Шкільний театр у такому випадку стає однією із форм реалізації методики "Філософія для дітей", метою якої є комплексне виховання культурно розвиненої, гармонійної особистості, відкритої до світу, його краси й радощів, тривог і проблем.

Аналіз останніх досліджень і публікацій, в яких започатковано розв'язання даної проблеми. На сьогодні розроблена професором філософії університету Монклер М. Ліпманом у 70-х роках ХХ століття методика "Філософія для дітей" активно впроваджується у багатьох країнах - США, Канаді, Китаї, Японії, Південній Кореї, Австралії, Німеччині, Австрії, Словаччині. Як зазначає дослідниця О. Дудник, американський новатор М. Ліпман винайшов багато універсальних принципів, до яких можна застосовувати приклади з національної та світової культури [2]. Наразі в Україні педагогічна стратегія "Філософія для дітей" перебуває в колі наукового пошуку вчених Н. Адаменко, С. Ганаби, І. Дичківської, Ю. Кравченко, О. Лесюка, І. Міщенко, Ю. Наріжного, Л. Пікуль та інш.

Рефлексія наукового доробку вчених України і світу з "Філософії для дітей" дозволяє стверджувати, що ця методика покликана формувати у підростаючого покоління критичне, креативне та піклувальне мислення, допомагати дітям і молоді долати без потрясінь різні соціальні ситуації, плавно входити у "дорослий світ", маючи досвід діалогу й дискусії. Дослідження вчених Л. Бочкаревої, Л. Ворошніної, Н. Карпінської, І. Медвєдєвої, О. Пометун, І. Реуцької, Л. Фурміної, Т. Шишової та ін. продемонстрували тісний зв'язок розвитку вищезазначених особливостей учнів і їхніх художніх здібностей. В цьому випадку вибір театральної форми роботи зумовлений iї ефективністю в активізації творчого потенціалу учня та розвитку його загальної культури й особистості в цілому. На значенні театру як обов'язкового елементу системи виховання гармонійної, всебічно розвиненої особистості молодої людини наголошував відомий чеський педагог-гуманіст Я. Коменський у своєму "Законі про театральні вистави" [3: 170]. Суголосною є думка українського педагога В. Сухомлинського, який вважав, що "казка, гра, неповторна дитяча творчість - вірний шлях до серця дитини" [1: 81]. Підтверджують ці висновки сучасні вчені, які 
визначають театралізовану гру як таку, що створює максимальні умови для вільного емоційного контакту учнів з дорослими й однолітками, сприяє формуванню доброзичливості та взаємної довіри, розвиткові навичок самоаналізу та самоконтролю. Педагогічну значущість театру висвітлено у науковому доробку дослідників І. Зязюна і Л. Масол, теоретико-методичні засади театральної діяльності підростаючого покоління запропоновано у наукових працях вчених Н. Миропольської, Т. Гризоглазової та інших.

Переваги театру як інтерактивної форми навчання й виховання учнів особливо виявляються, на нашу думку, в роботі з підлітками уразливих категорій. Деякі питання уразливості молодого покоління досліджено в роботах тих вчених, що аналізують труднощі психолого-педагогічної роботи з підлітками у процесі їхьої соціалізації (В. Бочарова, І. Кон, А. Макаренко), проблеми визначення підлітками свого місця в соціумі у різних соціально-педагогічних умовах $є$ предметом наукової уваги дослідників I. Звєрєвої, А. Капської, Ж. Петрочко.

Виокремлення невирішених раніше аспектів поставленої проблеми. Незважаючи на те, що сучасна педагогічна думка пропонує широкий спектр наукових розвідок, які розглядають проблему застосування театру в школі у різноманітних аспектах, на цей час можемо констатувати недостатність досліджень, присвячених шкільному театру як формі реалізації методики "Філософія для дітей", а також впливові театру на виховання підлітків уразливих категорій.

Формулювання мети статті. 3 огляду на викладене вище, вважаємо доцільним визначити метою своєї статті окреслення проблемного поля застосування театру як форми реалізації методики "Філософія для дітей" у сучасній школі, зокрема, з метою виховання підлітків уразливих категорій.

Виклад основного матеріалу дослідження. На думку дослідника Ю. Наріжного, функції вчителя, що реалізує інноваційну стратегію "Філософія для дітей" полягають "не в маніпулюванні інформацією, а у створенні певної культурної ситуації, що породжує уміння працювати із смислами, формує новий тип мислення. Його найважливіше завдання - формування культури розуміння і особистісного творчого потенціалу учнів" [4: 12]. Саме тому вважаємо вартим уваги те, що театральні форми роботи 3 учнями різних вікових категорій впроваджуються в рамках особистісної орієнтованості навчально-виховного процесу - врахування індивідуальних особливостей вихованців для вільного розвитку й повноцінного прояву можливостей і здібностей кожного учня з метою самоорганізації, самовиховання, саморегуляції поведінки, гармонійної взаємодії з оточуючим світом. Такий підхід відповідає виховній системі видатного педагога В. Сухомлинського, яка передбачає глибоку повагу до внутрішнього світу дитини й набуває особливої значущості в роботі з підлітками уразливих категорій.

У наш час психологія розглядає уразливість як підвищену чутливість особистості щодо дії різноманітних несприятливих чинників, таку "особистісну особливість, що робить людину залежною від будь-чого або будь-кого, іiї образливість, ранимість, наявність певної слабкості чи вади" [5: 168]. В підлітковому періоді уразливість значно підвищується, оскільки в цьому віці учні перебувають у перехідній віковій стадії від дитинства до юності, від незрілості до зрілості, яка характеризується багатьма фізичними та психологічними змінами особистості. Крім того, підліткова уразливість зумовлюється також політичною та економічною ситуацією в країні, впливом соціального оточення, зокрема однолітків, важкими сімейними умовами. Особливо це стосується підлітків 3 тимчасово переміщених родин. На сьогодні до уразливих відносять тих підлітків, які в силу певних обставин свого життя більш схильні до негативних зовнішніх впливів з боку суспільства. Ними можуть бути підлітки 3 проблемами у розвитку, які не мають певної клініко-патологічної характеристики; підлітки, які залишилися без піклування батьків через різні обставини; підлітки з асоціальних сімей; підлітки 3 родин, які потребують соціально-економічної та соціально-психологічної допомоги й інш. Для таких підлітків найціннішим у навчанні й вихованні є взаєморозуміння, взаємодія, взаємозбагачення учасників навчальновиховного процесу, обмін інформацією та досвідом, відмінними поглядами, різним світосприйняттям. Такі можливості для підлітків уразливих категорій відкриває шкільний театр. Саме тут учні мають змогу моделювати ситуації, спільно шукати шляхи розв'язання проблем.

Необхідність залучення підлітків до такої діяльності підкреслював В. Сухомлинський, який наголошував: "Наука і мистецтво виховання полягає передусім у тому, щоб уже з дитячих років, а особливо отроцтва і ранньої юності людина не тільки знала, пам'ятала, що таке добро і зло, а й вірувала і переживала добро і зло; вірувала й переживала в самій собі прагнення до добра, правди, честі, духовної непримиренності до зла, неправди, безчестя, потворності. Справжнє виховання полягає в тому, щоб моральний ідеал добра, правди, честі, духовної краси жив у кожному юному серці, утверджувався в активній діяльності як невід'ємна частина власного єства, власної думки, почуттів, намірів" [1: 27]. Театр, таким чином, дає можливість задіяти не лише розум підлітка, але і його емоції, вольові якості, спонукати його до творчості, тобто задіяти потенціал цілісної особистості. В діяльності театру втілюється метод "рівний - рівному", який передбачає вплив одних учнів на інших 3 метою зміни установок, переконань, поведінки останніх. Дослідники відзначають, що вистави за участю підлітків та молоді найкраще сприймаються саме підлітковою аудиторією, оскільки передавання інформації від однолітка до однолітка відбувається простіше й природніше через знання особливостей своєї 
субкультури, проблем підлітків і шляхів їх вирішення, натомість доступність дорослих до підліткового середовища обмежена віком, соціальним статусом, стилями комунікації й ін. Особливу ефективність в роботі з підлітками уразливих категорій показав форум-театр.

Тематикою вистав форум-театру, як правило, є ситуації пригнічення й насильства у найрізноманітніших проявах, тому сам театр називається "Театр пригнічених". Пригнічені - це ті люди або групи, які за своєю расовою, національною, статевою, соціальною, культурною, політичною, економічною чи ін. ознакою позбавлені свого права на діалог і повагу до себе, на участь у людському суспільстві на рівноправних засадах тощо. Оскільки підлітки уразливих категорій, в більшості випадків, як показали наші індивідуальні опитування та групові бесіди в експериментальних загальноосвітніх навчальних закладах, відмічають у себе внутрішній неспокій i невпевненість, відсутність самоповаги, відчуття "меншовартісності", недовіру, а іноді й відверту неприязнь чи агресію до "ворожого" оточуючого світу, театр пригнічених, відповідаючи їх внутрішньому стану, дозволяє вивести його "назовні" i, тим самим, подолати. В цілому, театр пригнічених - це світовий ненасильницький естетичний рух, який шукає миру, проте не визнає пасивності й завжди запрошує всіх присутніх до діалогу. Саме тому ця форма роботи на сьогодні використовується приблизно в половині країн світу як засіб перетворення суспільства, як спосіб відкриття себе та інших, як можливість самих людей змінити несприятливі обставини. Форум-театр звертається до кожного і "працює" на кожного. Головна мета вистав такого театру - дати можливість людині не лише усвідомити проблему і сформувати своє ставлення до негативного явища, а й здобути навички пошуку шляхів для вирішення проблеми з використанням власного досвіду та досвіду інших людей, включаючи можливості підсвідомості та емоційного інтелекту. Через це театр пригнічених визначається часто як система вправ, що допомагають кожній людині розвинути в собі найсуттєвіші "людські" якості [6].

Специфіка проведення форум-театру для підліткової аудиторії полягає в наступному: 1) вибір проблеми 3 орієнтацією на реальні історії; 2) використання аргументів, у тому числі, реальних цифр, які показують справжній стан справ; 3) емоційний компонент; 4) задіяність глядачів не тільки в обговоренні того, що відбувається на сцені, але й в інтеракціях з акторами.

У ході вистави форум-театру в ній можуть взяти участь всі бажаючі. Веде виставу джокер, або модератор. Перед початком вистави джокер форум-театру знайомить усіх присутніх з проблемою, що іiі висвітлюватиме вистава. Акторська група розігрує ситуацію з реального життя, а потім присутні мають змогу "прожити" цю ситуацію на місці головної дійової особи, намагаючись покращити становище героя. За сценарієм діють "жертва" - протагоніст, "агресор" - антагоніст, "свідки". Під час розробки сценарію обов'язково враховується, що основою будь-якої драматичної дії $\epsilon$ конфлікт, і тому сцена має завершуватись на його вершині, а конфлікт має бути свідомо доведений до максимальної гостроти. Джокер на протязі вистави має 3'ясувати, чи усвідомлюють глядачі, хто саме потерпає від пригнічення у змальованій ситуації, а хто, свідомо чи ні, стає пригноблювачем. Вистава зупиняється на кульмінаційному моменті, і тоді джокер запитує зал, що саме можна змінити на краще в цій ситуації. Один з глядачів, хто знає відповідь на питання джокера, заміняє головного героя, і вистава програється вдруге. Однак у ході постановки кожна людина, не чекаючи зупинки джокера, може сказати "Стоп!", зупинити хід вистави і програти ситуацію по-іншому, щоб власним прикладом показати, як, на її погляд, протагоніст міг би діяти конструктивніше [6].

Форум-театр як форма реалізації методики "Філософія для дітей", у першу чергу, сприяє розвиткові креативного мислення підлітка - учень під час підготовки вистави аналізує різні історії та ситуації, шляхом "мозкового штурму" разом з іншими відбирає певну історію, бере участь в написанні сценарію та відпрацюванні його елементів. У процесі роботи і безпосередньої презентації вистави підліток вчиться критично мислити: під час "проживання" певних ситуацій він виявляє вміння бачити глибину проблеми, приймає рішення, керуючись власним життєвим досвідом і знанням справи, вчиться вести діалог та дискусію, зокрема, аргументувати своє рішення, уникаючи конфліктів, прислухатись до думок і оцінок оточуючих та гідно приймати критику на свою адресу. Крім того, весь хід роботи від задуму до показу є результатом спільної роботи команди, внеску кожного в реалізацію загальної ідеї, завдяки чому в кожного 3 учасників формується піклувальне мислення - відкривається можливість, а іноді й необхідність, розуміти і приймати іншого, підтримувати одне одного, довіряти й довірятися, виявляти терпимість до тих партнерів по сцені, хто не одразу "вловлює" нюанси постановки, вирішуються суперечливі ситуації на засадах доброзичливості, чуйності й самовладання, аналізується емоційний досвід взаємодії з іншими людьми - власні враження, упередження, поведінкові реакції, стереотипи. При цьому будь-який учасник впізнає себе як партнера по спілкуванню, відкриває в собі найрізноманітніші сторони особистості: ті, які допомагають встановлювати гармонійні контакти з оточуючими, й ті, що заважають цьому. Значення такої спільної творчої діяльності для формування ціннісного ставлення учнів до самих себе й до оточуючих глибоко усвідомлював В. Сухомлинський: "Шкільне життя має бути таким, щоб у ньому завжди діяла система відповідальності людини за людину, відповідальності людини перед суспільством. Людина - колектив - суспільство - ось та система взаємовідносин, завдяки якій колектив стає силою, що виховує активного громадського діяча, дуже чутливого до громадських, суспільних потреб" [1: 79]. Ці зазначені вище результати переконливо підтверджують ефективність форум-театру як 
форми реалізації методики "Філософія для дітей" в роботі 3 підлітковою аудиторією, особливо 3 підлітками уразливих категорій.

Висновки. Методику "Філософія для дітей", форум-театр зокрема, завдяки низці наведених нами переваг вважаємо платформою для потужних перетворень в освітньому середовищі загальноосвітнього навчального закладу. Її впровадження у навчально-виховний процес допоможе утримати підлітків від поведінки, яка може їм зашкодити або призвести до потрапляння в кризові чи небезпечні ситуації, а також сприятиме формуванню людини нового типу - самостійної, відповідальної, критичної, здатної до саморозвитку, із власною позицією щодо морально-етичних ситуацій нашого життя, готовою до викликів сучасності.

Перспективи подальших розвідок у досліджуваному напрямі. На нашу думку, позитивна соціалізація підлітків уразливих категорій у наш час можлива за умов поєднання класичної педагогічної спадщини, в тому числі ідей В. Сухомлинського, та новітніх навчально-виховних методик. Саме тому ми переконані у перспективності заявленої теми, зокрема, в необхідності розробки освітніх програм за методикою "Філософія для дітей" із їхнім подальшим застосуванням у роботі з різними категоріями уразливих підлітків.

\section{СПИСОК ВИКОРИСТАНИХ ДЖЕРЕЛ ТА ЛІТЕРАТУРИ}

1. Сухомлинський В. О. Проблеми виховання всебічно розвиненої особистості / В.О.Сухомлинський // Вибрані твори в 5 т. / [ред. кол.: О. Г. Дзеверін (голова) та ін.]. - К. : Рад. шк., 1976. - Т. 1. - С. 53-206.

2. Дудник О. В. "Філософія для дітей" - інноваційна концепція та практика формування демократичного світогляду нового покоління [Електронний ресурс]/ О. В. Дудник. - Режим доступу : http://osvita.ua/school/lessons_summary/education/46087/.

3. Коменский Я.А. Избранные педагогические сочинения в 2 т. / Я. А. Коменский [под ред. А. А. Красновского]. - М. : Учпедгиз, 1955. - Т. 2. - 288 с.

4. Наріжний Ю. О. Чи будуть діти в Україні навчатися філософії в школі? / Ю. О. Наріжний // Постметодика. 2013. - № 6 (115). - C. 9-14.

5. Нечерда В.Б. Формування просоціальної поведінки підлітків уразливих категорій у загальноосвітніх навчальних закладах: до проблеми дослідження / Валентина Кириченко, Валерія Нечерда, Тетяна Тарасова // Психолого-педагогічні проблеми сільської школи : [збірник наукових праць Уманського державного педагогічного університету імені Павла Тичини] / [ред. кол. : Безлюдний О. І. (гол. ред.) та інші]. - Умань : ФОП Жовтий О. О., 2017. - Випуск 56. - С. 167-174.

6. Нечерда В. Б. Педагогічні умови виховання толерантності старших підлітків у навчально-виховному процесі загальноосвітньої школи : дис. ... канд. пед. наук : 13.00.07 / Нечерда Валерія Борисівна. - Київ, 2015. $297 \mathrm{c}$.

\section{REFERENCES (TRANSLATED \& TRANSLITERATED)}

1. Sukhomlynskyi V. O. Problemy vykhovannia vsebichno rozvynenoi osobystosti [Problems of Education of a Fully Developed Personality] / V. O. Sukhomlynskyi // Vybrani tvory v 5 t. [Selected Works in 5 Volumes.]. - Kyiv: Rad. shk., 1976. - S. 53-206.

2. Dudnyk O. V. "Filosofiia dlia ditei" - innovatsiina kontseptsiia ta praktyka formuvannia demokratychnoho svitohliadu novoho pokolinnia ["Philosophy for Children" is an Innovative Concept and Practice of Shaping the Democratic Worldview of a New Generation] / O.V. Dudnyk. - Rezhym dostupu : //osvita.ua/school/lessons_summary/education/46087/.

3. Komenskyi Ya. A. Izbrannyie pedagogicheskie sochineniia v 2 t. [Selected Pedagogical Works in 2 Volumes] / Ya. A. Komenskyi. - M. : Uchpedhyz, 1955. - T. 2. - $288 \mathrm{s.}$

4. Narizhnyi Yu. O. Chy budut' dity v Ukraini navchatysia filosofii v shkoli? [Will Children in Ukraine Learn Philosophy at School?] / Yu. O. Narizhnyi // Postmetodyka [Postmethodology]. - 2013. - № 6 (115). - S. 9-14.

5. Necherda V. B. Formuvannia prosotsial'noi povedinky pidlitkiv urazlyvykh katehorii u zahalnoosvitnikh navchal'nykh zakladakh: do problemy doslidzhennia [Formation of Pro-Social Behavior of Vulnerable Teenagers in Secondary Schools : to the Problems of Research] / Necherda V., Kyrychenko V., Tarasova T. // Psykholohopedahohichni problemy sils'koi shkoly [Psychological and Pedagogical Problems of a Rural School] : [zbirnyk naukovykh prats' Umans'koho derzhavnogo pedahohichnoho universytetu imeni Pavla Tychyny]. - Uman', 2017. Vol. 56. - S. 167-174.

6. Necherda V. B. Pedahohichni umovy vykhovannia tolerantnosti starshykh pidlitkiv u navchal'no-vykhovnomu protsesi zahalnoosvitnioi shkoly [Pedagogical Conditions of Moral Education of Tolerance of Senior Teenagers in Educational Process of Secondary Schools] : dys. kand. ped. nauk : 13.00.07 / Necherda Valeriia Borysivna. - Kyiv, 2015. - $297 \mathrm{~s}$.

\section{Нечерда В. Б. Форум-театр как форма реализации "Философии для детей": к вопросу воспитания подростков уязвимых категорий.}

Статья посвящена некоторым вопросам воспитания подростков уязвимых категорий в общеобразовательном учебном заведении. Автор раскрывает преимущества методики "Философия для детей", в частности, такой формы её реализачии как школьный театр. В ичентре внимания 
исследователя особенности форум-театра как интерактивной формы обучения и воспитания учеников и его эффективность в работе с подростками уязвимых категорий.

Ключевые слова: уязвимость, икольный театр, креативное мылиение, критическое мылиление, заботливое мыиление.

\section{Necherda V. B. Forum-Theater as a Form of Realization of "Philosophy for Children": to the Issue of Education of Adolescents of Vulnerable Categories.}

The article considers one of the acute problems of our time - the vulnerability of adolescents. The author studies domestic and foreign psycho-pedagogical literature, determines the concept of vulnerability, characterizes adolescents of vulnerable categories and emphasizes that most vulnerable teenagers are characterized by intolerance, prejudice, an indifferent social position, manifestations of antisocial behavior and formal thinking. The article also reveals the advantages of the "Philosophy for Children" methodology, in particular, the form of its implementation as a school theater. The focus of the researcher is the features of the forum theater as an interactive form of training and education of students and its effectiveness in dealing with adolescents of vulnerable categories. The author gives the results of individual interviews and group interviews in experimental educational institutions. Their data indicate that adolescents of vulnerable categories are prone to distrust, uncertainty, aggression to the world around them. Forum-theater responds to the internal state of vulnerable teenagers, allows it to be taken outside and thereby overcome. In the author's opinion, the use of the peer-topeer method is especially important in this case. The researcher comes to the conclusion that the forum-theater as a form of implementation of the methodology "Philosophy for Children" contributes to the formation critical, creative, caring thinking in adolescents of vulnerable categories. Thus, this methodology, and forum-theater, in particular, is a platform for powerful transformations in the educational environment of general educational institutions.

Key words: vulnerability, school theatre, critical thinking, creative thinking caring thinking. 